\section{Hastaların Müş̧teri İliş̧ileri Yönetimi Uygulamalarına İlişkin Algı Düzeylerinin Yapısal Eşitlik Modeli İle İncelenmesi}

\section{Derya Fatma BiçeR ${ }^{1}$}

\begin{tabular}{ccc}
\hline Geliş Tarihi/ Received & Kabul Tarihi/ Accepted & Yayın Tarihi/ Published \\
31/01/2020 & $06 / 07 / 2020$ & $15 / 07 / 2020$ \\
\hline Citation/Atıf: Biçer, D. F., (2020), Hastaların Müssteri İlişkileri Yönetimi Uygulamalarına \\
İişskin Algı Düzeylerinin Yapısal Eşitlik Modeli İle İncelenmesi, Atatürk Üniversitesi İktisadi ve \\
İdari Bilimler Dergisi, 34(3): 829-851, DOI: 10.16951/atauniiibd.682899 \\
\hline
\end{tabular}

Öz: Bu çalışmanın amacı Sivas Cumhuriyet Üniversitesi Sağlık Hizmetleri Uygulama ve Araştırma Hastanesi'nde (SCÜH) hizmet kalitesini ve müşteri memnuniyetini sağlamayı hedef alan müşteri ilişkileri yönetimi uygulamalarının hasta perspektifinden değerlendirilmesidir. Araştırmanın verilerinin elde edilmesinde genel tarama modeli kullanılmıştır. Müşteri ilişkileri yönetimi yaklaşımı müşteriyi işletmenin odak noktasına yerleştiren ve müşteri memnuniyetinin ötesine geçip, müşteriye değer sağlamayı hedefleyen müşterilere yönelik olarak uygulanacak temel pazarlama stratejilerinden biridir. Araştırmanın örneklemi 390 hastadan oluşmaktadır. Anketi cevaplayanların müşteri ilişkileri yönetimi uygulamalarına ilişkin algı düzeyleri orta seviyede çıkmış olup, hastanenin bu noktada daha fazla çalışması gerektiği düşünülmektedir. Katılımcıların algı düzeyleri ile medeni durum, yaş, sigorta türü değişkenleri arasında istatistiksel olarak anlamlı ilişkiler tespit edilirken, cinsiyet, eğitim düzeyi ve meslek değişkenlerine göre anlamlı ilişkiler bulunamamıştır.

Anahtar Kelimeler: Müşteri İlişkileri Yönetimi, Hasta, Hastane, Alg1

\section{Investigation of Perceptual Levels of Patoints Related to Customer Relationship Management Practices, with The Structural Equality Model}

Abstract: The aim of this study is, by means of the customer perspectives, to evaluate the customer relationship management practices which intend to provide the quality of services and customer satisfaction in Sivas Cumhuriyet University Health Services Training and Research Hospital (SCUH). The general survey model was used for obtaining the data of the research. The perspective of customer relationship management, which places the customer in the centre of the hospital and aims to add value to the customer by going beyond the customer satisfaction, is one of the major marketing strategies towards the customer applications. The sample group of the study consists of 390 patients. The customer relationship management perception means of the ones who answered the questionnaire is intermediate level, and in this context, it was determined that the hospital must work more. While the perception means of the participants were found statistically significant by marital status, age and the type of insurance, it was found insignificant by the gender, level of education and employment.

Keywords: Customer Relationship Management, Patient, Hospital, Perception

${ }^{I}$ Dr. Öğr. Üyesi, Sivas Cumhuriyet Üniversitesi, İktisadi ve İdari Bilimler Fakültesi, Issletme Bölümü, Üretim Yönetim ve Pazarlama Ana Bilim Dall, https://orcid.org/0000-0002-3359-1236 
Hastaların Müssteri İlişkileri Yönetimi Uygulamalarına İliş̧kin Algı Düzeylerinin Yapısal Eşitlik Modeli İle İncelenmesi

\section{EXTENDED SUMMARY}

\section{Research Problem}

This study carried out in Sivas Cumhuriyet University Health Services Training and Research Hospital (SCÜH) to evaluate the customer relationship management practices that aim to provide service quality and customer satisfaction through the patient perspective is important to reveal the significance of customer relationship management in hospitals. In literature, there are many studies on customer relations management, but very few studies were found to evaluate the relationship in health institutions. That is why, this study is important.

\section{Research Questions}

The answers to the following questions are sought in accordance with the purpose of the study:

1) What is the perception level of patients about the practices on customer relationship management?

2) Are there any relations between the socio-demographic characteristics of patients and their perception level on the practices of customer relationship management?

\section{Literature Review}

CRM applications bring many positive innovations in health services as they do in other businesses. In this context, CRM is important in order to balance the ever-increasing cost of healthcare services that directly contribute to social welfare, economic efficiency and the happiness of individuals. When literature analysed, the effect of CRM is related to conventional tools and the use of peopleoriented tools, and it is observed that it is gradually used effectively in health services as well. Moreover, it is seen that patient information system (PIS) used in health services is also important on CRM effectiveness.

\section{Methodology}

The general survey model was used to obtain the research data. After taking the ethical committee and the institution permissions, the questionnaires were distributed to the patients who took services in SCUH. The sample group of the study consists of the 390 inpatients and outpatients who applied to the institution between 10/05/2019 and 01/06/2019. In the study, in order to evaluate the perception of the patients on the customer relationship management, 'The Customer Relationship Management (CRM) Perception Scale' which was developed by Agariya and Singh (2013) and then translated into Turkish language was used. A minimum of 25 points and a maximum of 125 points can be obtained from the scale. The scale items were answered by the participants in a five-point Likert structure as "1: Strongly Disagree, 2: Disagree, 3: Neither Agree nor Disagree, 4: Agree, 5: Strongly Agree". SPSS 25.0 and AMOS 23 were used for the analyses of the data. In order to determine the normal distribution of points, Kolmogorov-Smirnov (K-S) test was applied and the data were found to be normally distributed. ANOVA and independent t-test were applied in order to 
determine whether the customer perception means of customer relationship management practices become significantly different in terms of the demographic variables. The level of failure was taken as 0.05 . According to the data obtained at the end of the research, the Cronbach Alpha value of The Customer Relationship Management Perception Scale is found to be 0.90 .

\section{Results and Conclusions}

According to the data obtained at the end of the research, $58.7 \%$ of the patients stated that they waited less than 20 minutes for the services, but the other half said that they waited more than 20 minutes for the services. It is found that the patients who answered the questionnaire have intermediate level perception means on customer relationship management practices. Therefore, it is determined that the hospital must work harder. When the results analysed in terms of demographic variables, it was found that the means of CRM perception level of participants are statistically significant by marital status, age and the type of insurance, they are statistically insignificant by the gender, level of education and employment. The perception level of married ones were found higher than the single ones. Furthermore, it was determined that as the age increases, the perception level of customer relationship management increases. Similarly, the perception means were found higher in individuals who go through regular health check-ups than those who do not. It was determined that the perception level means of men are higher than the women's, but these means are not statistically significant. Considering that women are more obsessed with the details, this result is plausible. Based on the research findings, it is suggested that hospitals must give importance to customer relationship management practices and develop strategies to provide services of good quality.

\section{Giriş}

Günümüz işletmelerinin devamlılıklarını sağlayabilmelerinin temel şartı müşteri memnuniyeti ve sadakatidir. Sağlıkta özelleştirmenin artmasıyla birlikte sağlık kurumları da bu rekabet koşullarına ayak uydurmak zorunda kalmıştır. Ürettiği hizmetin niteliği nedeniyle en fazla paydaşa sahip olan sağlık kurumlarında müşteri ilişkileri yönetimi; tatminkâr bir hizmet kalitesi yaratmak, bunun devamlılığını sağlamak için büyük öneme sahiptir. Hastalar da bu paydaş grubunun en önemli ve temel halkasını oluşturmaktadır. Bu noktadan hareketle diğer sağlık kurumlarına (aile hekimliği vb.) göre daha fazla hastanın başvuru yaptığı, hastaneler için müşteri ilişkileri yönetimi uygulamalarını hayata geçirmiş olmaları ve hastaların da bu husustaki algılarının değerlendirilmesi stratejik olarak oldukça önemlidir. Birçok ülkede artık sağlık hizmetlerinin sunumunda hastane ve müşteri arasında bir güven köprüsü oluşturma aracı olarak Customer Relations Management (CRM), dilimize Müşteri İlişkileri Yönetimi (MIY) olarak yerleşmiş olan CRM uygulamaları tercih edilmektedir. MIY sistemi, sağlık işletmelerinin temel müşteri bilgilerini almasını ve mümkün olduğunca verimli kullanmasını sağlamaktadır. MiY, sağlık hizmeti sunmak için senkronize bir yaklaşımla bir dizi yeni metodlar da düzenlemektedir (Yina, 2010: 52). 
Hastaların Müsteri Illişkileri Yönetimi Uygulamalarına İlişkin Algı Düzeylerinin Yapısal Eşitlik Modeli İle İncelenmesi

$\mathrm{Bu}$ bağlamda, müşteri ilişkileri yönetimi yaklaşımı; günümüz işletmelerinde hem stratejik yönetimin etkili bir aracı, hem de müşterilere yönelik olarak uygulanacak temel pazarlama stratejilerinden biri olan, müşteriyi işletmenin odak noktasına yerleştiren ve müşteri memnuniyetinin ötesine geçip, müşteriye değer sağlamayı hedefleyen bir sistemdir (Sumathy and Tamilselvan, 2008). Müşteri ilişkileri yönetimi, müşteri seçimi, müşteri edinme, müşteri koruma ve müşteri derinleştirme evrelerinden oluşmaktadır (Aktepe vd. 2018: 5).

Günümüzde yeni müşteriler edinmek, mevcut müşteriye ulaşmaktan çok daha zordur. Var olan müşterilerin, kuruma olan bağl1lığını korumak ve arttırmak müşteri ilişkileri yönetiminin var olma nedenlerinden biridir. Müşteri kavramı, sağlık kurumlarında sadece hastaları değil; tedarikçiler, çalışanlar, sosyal güvenlik kurumu, paydaşlar vb. tüm iç ve dış müşterileri içermektedir. Fakat hastanelerde müşteri ilişkileri yönetiminin temel amacı, hastaları memnun etmek ve hasta sadakatini artırmaktır. Çünkü hastanelerin sunduğu hizmetlere sadık olan hastanın tedavi süreci de daha hızlı ve olumlu sonuçlanacaktır. Müşteri ilişkileri yönetimi iç ve dış müşteri tatmini, sadakati ve müşteri değeri yaratmak için yapılan stratejik ve birbiri ile ilişkili bir süreci ifade etmektedir. Müşteri tatminini sağlayabilmek, müşteri yönlü düşünmeyi, müşteriye yakın olmayı, müşterinin sesine kulak vermeyi, müşteri ile iyi ilişkiler kurmayı ve bu ilişkilerin sürekliliğini sağlamayı gerektiren bir faaliyettir. Bunu sağlayabilmek için müşterilerin beklentileri sürekli olarak analiz edilmektedir. Odabaş1 (2017: 6) bu noktada müşterilerin; karşılık görebilme, bilgili çalışanlar, hız, sözlerin tutulması, anlayış, güven, takip etme, hatasız işlem, tutarlılık, iletişim, ulaşılabilirlik ve birebir iletişim beklediklerini ifade etmiştir. Esasında ilgili yazın incelendiğinde sıralanan bu değişkenlerin hizmetkâr liderlik stratejisi geliştirmek adına önemsenmesi gereken hizmet kalitesi bileşenlerini kapsadığı görülmektedir. Bilhassa doğrudan insana dokunan ve bilişsel, duygusal ve davranışsal tutumların ve davranışsal niyetlerin oluşmasında oldukça etkili olan sağlık hizmetlerinde bu faktörlerin her biri oldukça önemli ve gereklidir. Sağlık hizmetlerinde bunu sağlamanın yolu ise müşteri ilişkileri yönetimini güçlendirmekten geçmektedir.

MIY uygulamaları diğer işletmelerde olduğu gibi sağlık hizmetlerinde de birçok olumlu yenilikler getirmektedir. Bu bağlamda toplumsal refaha, ekonomik verimliliğe ve bireylerin mutluluğuna doğrudan katkıda bulunan sağl1k hizmetlerinin sürekli artan maliyetinin (Karagöz ve Ilıman, 2019: 1035) de dengelenebilmesi için MIYY önemlidir. İlgili yazın incelendiğinde MİY'in etkinliğinin, geleneksel araçların ve insan odaklı araçların kullanımı ile ilgili olduğu ve her geçen gün sağlık hizmetlerinde de etkin olarak kullanıldığı görülmektedir (Yina, 2010; Fok vd. 2003). Aynı zamanda sağlık hizmetlerinde kullanılan Hastane Bilgi Sisteminin (HBS)' de MiY etkinliğinde önemli olduğu görülmektedir (Choi vd. 2013). HBS, hastanelerin kurumsal yapılarına göre farklı amaçlara hizmet edecek ve verimliliği artıracak şekilde entegre edilebilmektedir (Eriş ve Ilıman, 2019: 302). Bu nedenle MiY uygulamalarında da etkin olarak yer almaktadır. 


\section{Kavramsal Çerçeve}

Müş̧eri ilişkileri yönetimi; müşteri ile ilişkide bulunulan her alanda müşteriyi daha iyi algılama ve onun beklentileri çerçevesinde firmanın kendini daha iyi yönlendirmesi sürecidir. Müşteri ilişkileri yönetimi, işletmenin satış, Hizmet ve pazarlama bölümlerinin, bireysel müşteriler hakkında sahip oldukları tüm bilgileri bütünleştiren, derinlemesine analiz eden ve daha güçlü müşteri ilişkileri kurmak için, gelişmiş yazılımlar ve analitik araçları kullanan bir yaklaşımdır (Çiçek, 2017:18).

Müşteri ilişkileri yönetiminin amaçları;

$>$ Müşteri ilişkilerini karlı hale getirmek

$>$ Farklılaşma sağlamak

$>$ Maliyet minimizasyonu sağlamak

$>$ İşletmenin verimini artırmak

$>$ Uyumlu faaliyetler sağlamak

$>$ Müşteri taleplerini karşılamak şeklinde sayılabilir.

İlgili yazında müşteri ilişsileri yönetimin temel unsurları olarak; iletişim güvenilirlik, karşılık verebilmek (duyarlılık), hizmet kalitesi, güvence, empati, fiziksel varlıklar, kullanılabilirlik ve ulaşılabilirlik kavramlarından bahsedilmektedir (Almunawar ve Anshari, 2014; Cho1, 2013; Khoshraftar vd. 2011)

Tablo 1'de MiY boyutları ve açıklamaları yer almaktadır.

Tablo 1: Müşsteri İlişkileri Yönetiminin Boyutları

\begin{tabular}{|c|c|}
\hline Boyutlar & Açıklama \\
\hline İletişim & $\begin{array}{l}\text { Müşteriler arasında kültür ve eğitim farklılıklarının dikkate } \\
\text { alınması suretiyle müşterileri bilgilendirme, sorunlarının dinlenip } \\
\text { cözümlerinin sağlanması. }\end{array}$ \\
\hline Güvenilirlik & $\begin{array}{l}\text { Hizmetin doğruluğu, tutarlığı ve ilgili hizmeti vaat edildiği şekilde } \\
\text { gerçekleştirebilme. }\end{array}$ \\
\hline $\begin{array}{l}\text { Karşıllı } \\
\text { Verebilmek }\end{array}$ & Müşterilerin isteklerine zamanında ve yeterince cevap verebilme. \\
\hline Hizmet Kalitesi & $\begin{array}{l}\text { İşletmenin müşteri beklentilerini karşılayabilme ve geçebilme } \\
\text { yeteneği. }\end{array}$ \\
\hline Güvence & Çalışanların müşteri üzerinde güven duygusu yaratabilmesi \\
\hline Empati & Kendini müşterinin yerine koyabilme yeteneği. \\
\hline $\begin{array}{l}\text { Fiziksel } \\
\text { Varlıklar }\end{array}$ & $\begin{array}{l}\text { Hizmet verilen ortamın görüntüsü, konforu, kullanılan malzeme ve } \\
\text { ekipmanları ifade etmektedir. }\end{array}$ \\
\hline Kullanılabilirlik & $\begin{array}{l}\text { İşletmenin belirlenen amaçlara ne derece ulaşıldığının (etkililik), } \\
\text { belirlenen amaçların elde edilmesi için harcanması gereken zaman, } \\
\text { para, zihinsel çaba vb. kaynakların (etkinlik) ve kullanıcının, } \\
\text { sistemi kabul edilebilir bulma derecesinin (tatmin) bir ölçüsü. }\end{array}$ \\
\hline Ulaşılabilirlik & $\begin{array}{l}\text { Hizmete ulaşmak için gerekli fiziki koşulların sağlanması ve } \\
\text { iletişim araçlarıyla hizmete kolay erişimin desteklenmesini ifade } \\
\text { etmektedir. }\end{array}$ \\
\hline
\end{tabular}

Kaynak: Almunawar ve Anshari, 2014; Cho1, 2013; Khoshraftar vd. 2011 
Hastaların Müsteri Illişkileri Yönetimi Uygulamalarına İlişkin Algı Düzeylerinin Yapısal Eşitlik Modeli İle İncelenmesi

$\mathrm{Bu}$ bağlamda sağlık kurumlarında müşteri ilişkileri yönetimi; hasta ve yakınlarının beklentilerini, isteklerini belirlemek; doğru ve hızlı tedavi için gerekli kalite koşullarını sağlamak, hastalar ile sağlık çalışanlarının iletişimini güçlendirmek ve böylece hasta tatmini ve bağl1lı̆̆ 1 sağlamak için yapılan çalışmaların tümü olarak tanımlanabilir.

Oliver'a (2008) göre MiY'in değeri, müşterilerle iyi ve uzun vadeli ilişkiler kurmak ve sürdürmektir. Belirli ürün ve hizmetlerin müşteriler tarafından tekrar tekrar kullanılması anlamına gelen müşteri sadakati MiY için kritik öneme sahip bir kavramdır. Sadakat hizmete yönelik sadece tekrar eden tercihleri değil, memnuniyet algısının ağızdan ağıza paylaşılması ile artan potansiyel talebi de beraberinde getirecektir. Bu nedenle, sağlı hizmetlerinde MíY'in temeli, hastaların gereksinim ve isteklerini onların bekledikleri özen ile karşılamak ve hasta sadakat düzeyini arttırmaktır. Hasta ile sağlık hizmeti sağlayıcısı arasında yakın ilişkilerin kurulduğu yüz yüze temas ve karşılaşma anlarının yaşandığı hizmet sunumlarında kritik anlara dikkat etmek ve süreçleri doğru yönetmek gerekmektedir. Bu noktada tatmin belirleyicilerinden biri olan algilanan hizmet kalitesi düzeyini yükseltecek tedbirler almak ve operasyonlar düzenlemek önem arz etmektedir. Nitekim; Çobanoğlu (2012)'nun Müşteri İlişkileri Yönetimi'nin kamu sektöründe uygulanabilirliğini ve uygulama sonucunda elde edilecek sonucun neler olabileceğini ortaya koymak amacıyla yaptığ göre, müşteri ilişkileri yönetimi uygulamalarının, hastaların memnuniyetini artırdığı ve bu sayede hastaneyi tekrar tercih etmelerini ve başkalarına da tavsiye etmelerini sağladığı görülmektedir. Kılıç (2015)' 'n çalışmasında da müşteri ilişkileri yönetiminin algılanan kalite, tatmin ve marka sadakatini pozitif yönde etkilediği sonucuna ulaşılmıştır. Yine Almunawar ve Anshari (2014)'nin Müşteri İlişkileri Yönetimi aracılığıyla müş̧erilerin e-sağlık uygulamalarının yeterlilik düzeylerini değerlendirdikleri araştırmada; MiY uygulamaları neticesinde memnuniyetin hızlı bir şekilde artması ile katılımcıların e-sağlık hizmetlerini takdir ettikleri sonucuna varılmıştır. Benzer şekilde; Bişkin 2011 yılında sağlık işletmelerinden hizmet alan müşterilerin memnuniyetlerini etkileyen faktörleri tespit etmek amacıyla yaptığı doktora tezinde algıladıkları hizmet kalitesinin memnuniyetlerini olumlu yönde etkilediği sonucuna varmıştır.

Hastalar hastaneleri seçtiklerinde, hastanelerin kendi sağlikları hakkında doğru ve eksiksiz bilgiye sahip olduklarına inanmak istemektedirler. Doğru bir şekilde tasarlanmış MiY sistemi, hekimlerin ve diğer sağlık görevlilerinin demografik bilgilerini, hastanın geçmişini görüntülemelerine yardımcı olabilir. Hastaneler MiY uygulamaları sayesinde iş süreçlerini standartlaştırıp düzenleyebilirler; aynı zamanda bu uygulamalar hasta ve sağlık hizmet sunucularının proaktif iletişim kurmalarına yardımcı olabilir. Kısacası hastanelerde MiY hastaların hem fiziksel hem de ruhsal anlamda, yani genel olarak, sağlıklarını iyileştirmelerine yardımcı olmaktadır. Bunun yanı sıra bu uygulamalar dolaylı olarak, hastalar ek hizmetler aldıklarında, onları tatmin 
edecek ve bu da düzenli koruyucu sağlık hizmetlerine sürekli bir öncelik verilmesi olasıllğını artıracaktır (Chhangani, 2013: 405).

$\mathrm{Bu}$ bağlamda; Fok vd. (2003)'nin yaptı̆̆ araştırmada ise MiY uygulamalarının çalışanlar tarafından benimsenmesi ve hastalar tarafindan olumlu algılanması sonucunda etkin olacağı sonucuna varılmıştır. Bununla birlikte Yalın (2014)'ın araştırmasından çıkan en önemli sonuç çalışanlarla rahat ve kolay iletişim kurmanın hasta/hasta yakınları için en önemli önceliği teşkil etmesi olmuştur. Torabi (2014)'nin araştırma sonucuna göre ise cevaplayıcılar, MiY politika ve stratejisinde, müşteri ile uzun vadeli ilişki kurmayı en etkili faktör olarak görmektedirler. Ayrıca, müşteri bilgilerini toplamak ve yararlanmak üzere, firmada kapsamlı veri tabanı oluşturmak, katılımcılar tarafından gerekli görülmüştür. Soysal vd. (2017) tarafından yapılan çalışma neticesinde sağlık kurumlarının müşterileri olan hizmet alıcılarının memnuniyet düzeylerini en çok hizmet sunumu ve insan kaynakları (hekim, hemşire ve diğer personel) konusunda yapılan iyileştirmelerin etkilediği sonucuna varılmıştır.

\section{Araştırmanın Amacı ve Önemi}

Müşteri ilişkileri yönetiminin sağlık kurumları için önemi ve katkıları göz önüne alındığında, Sivas Cumhuriyet Üniversitesi Sağlık Hizmetleri Uygulama ve Araştırma Hastanesi'nde (SCÜH) hizmet kalitesini ve müşteri memnuniyetini sağlamayı hedef alan müşteri ilişkileri yönetimi uygulamalarının hasta perspektifinden değerlendirilmesi amacıyla yapılan bu çalışma hastaneler için de müşteri ilişkileri yönetiminin önemini ortaya koymak açısından önem arz etmektedir. Alan yazında müşteri ilişkileri yönetimi ile ilgili birçok çalışma mevcuttur, fakat sağlık kurumlarında değerlendiren çok az çalışmaya rastlanmıştır (Lecturer vd. 2018; Kayacan, 2015; Agariya and Singh, 2013; Chhangani, 2013; Çobanoğlu, 2012). Bu sebepten araştırma önemli görülmektedir.

Araştırmanın amacı doğrultusunda geliştirilen araştırma problemi ve hipotezler şöyledir:

$\mathrm{P}_{1}$ : Hastaların müşteri ilişkileri yönetimi uygulamalarına ilişkin algıları ne düzeydedir?

$\mathrm{H}_{1}$ : Hastaların cinsiyetleri ile müşteri ilişkileri yönetimi uygulamalarına ilişkin algı düzeyleri arasında anlamlı farklılık vardır.

$\mathrm{H}_{2}$ : Hastaların medeni durumları ile müşseri ilişkileri yönetimi uygulamalarına ilişkin algı düzeyleri arasında anlamlı farklılık vardır.

$\mathrm{H}_{3}$ : Düzenli sağlık kontrollerinden geçen hastalar ile geçmeyen hastaların müşteri ilişkileri yönetimi uygulamalarına ilişkin algı düzeyleri arasında anlamlı farklılık vardır.

$\mathrm{H}_{4}$ : Hastaların yaşları ile müşteri ilişkileri yönetimi uygulamalarına ilişkin algı düzeyleri arasında anlamlı farklılık vardır.

$\mathrm{H}_{5}$ : Hastaların eğitim düzeyleri ile müşteri ilişkileri yönetimi uygulamalarına ilişkin algı düzeyleri arasında anlamlı farklılık vardır. 
Hastaların Müş̧teri İlişkileri Yönetimi Uygulamalarına İlişkin Algı Düzeylerinin Yapısal Eşitlik Modeli İle İncelenmesi

$\mathrm{H}_{6}$ : Hastaların meslekleri ile müşteri ilişkileri yönetimi uygulamalarına ilişkin algı düzeyleri arasında anlamlı farklılık vardır.

$\mathrm{H}_{7}$ : Hastaların sağlı sigortası durumları ile müşteri ilişkileri yönetimi uygulamalarına ilişkin algı düzeyleri arasında anlamlı farklılık vardır.

$\mathrm{H}_{8}$ : Hastaların gelir düzeyleri ile müşteri ilişkileri yönetimi uygulamalarına ilişsin algı düzeyleri arasında anlamlı farklılık vardır.

\section{Yöntem}

$\mathrm{Bu}$ bölümde araştırmanın evren/örneklemi, veri toplama araçları, verilerin toplanması ve analizi ile ilgili bilgiler sunulmaktadır.

\subsection{Evren/Örneklem}

Araştırmanın verilerinin elde edilmesinde genel tarama modeli kullanılmışırı. Araştırmanın evrenini 10.05.2019 - 01.06.2019 tarihleri arasında, kuruma başvuran poliklinik (ayaktan) ve servis (yatan) hastaları oluşturmaktadır. Evren net olarak belirlenememiş; ortalama 30.000 olarak tespit edilmiştir. Sekeran (2003: 253) tarafından geliştirilmiş, evrenin 30.000 olduğu noktada örneklemin 379, üst sınırının ise 384 olarak kabul edildiği örneklem tablosuna göre; örneklem için 384 ve üstü kişiye ulaşılması hedeflenmiştir.

Örneklem seçiminde kolayda örnekleme yöntemi tercih edilmiş olup; etik kurul ve kurum izinleri alındıktan sonra, SCÜH'sinde, 10.05.2019 - 01.06.2019 tarihleri arasında, poliklinik ve servis hizmeti alan ve araştırmaya katılmayı kabul eden 390 hastaya anket dağıtılmıştır. Dolayısıyla araştırmanın örneklem grubunu bu 390 hasta oluşturmaktadır.

Tablo 2'de örnekleme ilişkin betimsel istatistikler sunulmaktadır.

Tablo 2: Katılımcıların Sosyo-Demografik Özellikleri

\begin{tabular}{llcc}
\hline Değişkenler & & Frekans (f) & Yüzde (\%) \\
\hline \multirow{2}{*}{ Cinsiyet } & Kadın & 218 & 55,9 \\
& Erkek & 172 & 44,1 \\
\hline \multirow{4}{*}{ Yaş } & $18-29$ & 111 & 28,5 \\
& $30-44$ & 109 & 27,9 \\
& $45-59$ & 89 & 22,8 \\
\multirow{2}{*}{ Medeni Durum } & 60 ve üstü & 81 & 20,8 \\
\hline \multirow{4}{*}{ Eğitim Düzeyi } & Evli & 231 & 59,2 \\
& Bekar & 159 & 40,8 \\
\hline \multirow{2}{*}{ İş } & Okur-yazar değil & 38 & 9,7 \\
& İlköğretim & 113 & 29,0 \\
& Lise & 88 & 22,6 \\
& Lisans & 116 & 29,7 \\
& Lisans Üstü & 35 & 9,0 \\
\hline & Çalışmıyor & 207 & 53,1 \\
& Kamu Çalı̧anı & 91 & 23,3 \\
& Özel Sektör Çalışanı & 92 & 23,6 \\
\hline
\end{tabular}


Derya Fatma BIÇER

Tablo 2 Devamı: Katılımcıların Sosyo-Demografik Özellikleri

\begin{tabular}{llcc}
\hline & $1.000 €$ ve altı & 96 & 24,6 \\
\multirow{3}{*}{ Gelir Seviyesi } & $1.000-.3 .000 €$ arası & 180 & 46,2 \\
& $3.001-5.000 €$ arası & 73 & 18,7 \\
& 5.001 € ve üzeri & 41 & 10,5 \\
\hline \multirow{2}{*}{ Sigorta } & GSS & 232 & 59,5 \\
& Özel Sigorta & 117 & 30,0 \\
& Güvencem yok & 41 & 10,5 \\
\hline Düzenli Sağlık & Evet & 179 & 45,9 \\
Kontrolü & Hayır & 211 & 54,1 \\
\hline \multirow{2}{*}{ Bekleme Süresi } & 0-20 dk & 230 & 59,0 \\
& $20 \mathrm{dk}$ üzerinde & 160 & 41,0 \\
\hline \multirow{2}{*}{ Toplam } & & 390 & 100.0 \\
\hline
\end{tabular}

Tablo 2 incelendiğinde, ankete katılan katılımcıların \%55,9'unun kadın, $\% 44,1$ 'inin erkek olduğu, büyük çoğunluğunun 18-44 yaş aralığında olduğu, $\% 40,8$ 'inin bekar ve \% 59,2'sinin evli olduğu görülmektedir. Katılımcilar ağırlıklı olarak ilköğretim ve lisans mezunudur ve katılımcıların, yaklaşık yarısı çalışmamaktadır. Çoğunluğunun gelir seviyesi 1.000 € 3.000 ₹ arasındadır. Katılımcıların yaklaşık 2/3'sinin GSS'na, 1/3'inin ise özel sigortaya sahip olduğu görülmektedir. Aynı zamanda hastaların yarısından fazlası düzenli sağlık kontrollerinden geçemediğini söylemiş̧ir. Hastaların \% 59'u işlemler için $20 \mathrm{dk}$ dan daha az, diğer yarısı ise $20 \mathrm{dk}$ 'dan daha fazla beklediğini belirtmiştir.

\subsection{Veri Toplama Aracl}

Alan yazında hastanelerde MiY ile ilgili araştırmalar sınırlı olup; çalışmalarda kullanılan ölçeğin hizmet kalitesi ölçümünde sıklıkla kullanılan SERVQUAL ölçeğindeki veya sadece hasta memnuniyeti ölçümünü içeren ifadelere yer verildiği görülmektedir. MIY kalitenin bir parçası olarak değerlendirildiğinde; hizmet kalitesi ölçüm modellerinden çok fazla ayırıcı özelliğinden bahsetmek mümkün olmamakla birlikte, alan yazın incelendiğinde, hastanelerde müşteri ilişkileri yönetiminde temel kavramlar; kurumun fiziksel şartları, hizmet kalitesi, iletişim, kolay erişilebilirlik, kullanımda hakkaniyet ve kolaylık, çalışanlara ve kuruma güven, hasta tatmini ve bağl1lı̆̆ olarak belirlenmiştir. (Hoşgör ve Cengiz, 2019; Nakip, 2015; Moreira and Silva, 2014).

Bu bağlamda; araştırma örnekleminin kamu hastanesi olması ve ölçekte yer alan faktörlerin MIY ölçümü için yeterli olarak görülmesi sebebiyle araştırma amacına en uygun ölçeğin Agariya ve Singh (2013) tarafindan Hindistan hastaneleri için geliştirilen; beş faktörden oluşan "Müşteri İlişskileri Yönetimi (MIY) Algısı Ölçeği” olduğu kanaatine varılmıştır. Bahsedilen çalışmada ölçeğin Hindistan için geliştirilmiş olması sebebiyle; araştırmacılar tarafından Türkçeye uyarlanan ölçeğin düzenlenmesinde, Çobanoğlu (2012)'nun araştırmasında kullandığ 1 ölçek ifadelerinden de yararlanılmış olup; uzman görüşleri doğrultusunda ölçek maddelerine son şekli verilmiştir. 25 ifadeden oluşan ölçekte 
Hastaların Müş̧teri İlişkileri Yönetimi Uygulamalarına İlişkin Algı Düzeylerinin Yapısal Eşitlik Modeli İle İncelenmesi

yapılan AFA ve DFA analizleri neticesinde faktörler altında yer alan 6 ifade çıkarılarak analizlere 19 ifade ile devam edilmiştir. Ölçek maddeleri katılımcılar tarafindan "1: Kesinlikle Katılmıyorum, 2:Katılmıyorum, 3: Ne Kat1lyorum Ne Katılmıyorum, 4:Katılıyorum, 5:Tamamen Katılıyorum" şeklinde beşli likert yapıda yanıtlanmıştır. Araştırmada kullanılan ölçeği oluşturan ifadelerin güvenilirliklerini test etmek amacıyla öncelikle iç tutarlık analizi sonuçlarına bakılması, iç güvenilirliğin (Cronbach Alfa katsayıs1) 0.60 üzerinde olması gerekmektedir (Karagöz, 2019: 69). Araştırma sonucunda elde edilen verilere göre müsşteri ilişkileri yönetimi algısı ölçeğinin Cronbach Alfa katsayısı 0.90 olarak saptanmış olup; güvenilirliğin oldukça yüksek olduğu görülmektedir.

\subsection{Verilerin Toplanmast ve Analizi}

Araştırmanın örneklem grubunu 10.05.2019 - 01.06.2019 tarihleri arasında, kuruma başvuran yatarak ve ayakta tedavi gören 390 hasta oluşturmaktadır. Verilerin analizinde SPSS 25.0 ve AMOS 23 istatistik programları kullanılmıştır. Puanların normal dağılıp dağılmadığını tespit etmek amaciyla Kolmogorov-Smirnov (K-S) testi uygulanmış ve verilerin normal dağ $11 ı$ gösterdiği tespit edilmiştir. Hastaların müşteri ilişkileri yönetimi uygulamaları algı düzeylerinin demografik değişkenlere göre anlamlı şekilde farklılaşıp farklılaşmadığını belirlemek amacıyla ANOVA ve bağımsız gruplar T testi kullanılmıştır. Yanılma düzeyi 0,05 olarak alınmıştır.

\section{Bulgular}

Araştırmanın bu bölümünde, araştırma sonucunda elde edilen bulgular ayrintılı olarak sunulmaktadır.

\subsection{MIY Algisı Ölçeğinin AFA ile Test Edilmesi}

Araştırmada kullanılan ölçeği oluşturan ifadelerin güvenilirliklerini test etmek amacıyla öncelikle iç tutarlık analizi yapılmıştır. Ardından teorik modelin yapısal geçerliliğini test etmek ve ölçeği oluşturan birbiriyle ilişkili temel boyutları değerlendirmek amacıyla, açıklayıcı faktör analizi yapılmıştır. Yapılan analizler ile elde edilen sonuçlar Tablo 3'te verilmiştir.

Tablo 3. Araştırma Modelini Oluşturan Faktörlere İlişkin AFA Sonuçları

\begin{tabular}{lcccc}
\hline Yargı İfadeleri & $\begin{array}{c}\text { Faktörün } \\
\text { Açıklayıcılığı \% }\end{array}$ & Özdeğer & Güvenilirlik & $\begin{array}{c}\text { Faktör } \\
\text { Yükleri }\end{array}$ \\
\hline Fiziksel Şartlar & $\mathbf{3 6 , 0 0}$ & $\mathbf{6 , 8 4}$ & $\mathbf{0 , 8 0}$ & \\
\hline M1: Hastanenin fiziki şartları benim için yeterlidir. & & & 0,83 \\
M2: Hastanenin tıbbi ekipmanları yeterlidir. & & 0,86 \\
M3: Hastanenin acil ve kritik bakım üniteleri yeterlidir. & & 0,80 \\
M4: Hastanenin hijyen ve temizlik şartları yeterlidir. & & 0,67 \\
\hline
\end{tabular}


Derya Fatma BIÇER

Tablo 3 Devamı: Araştırma Modelini Oluşturan Faktörlere İliş̧kin AFA Sonuçları

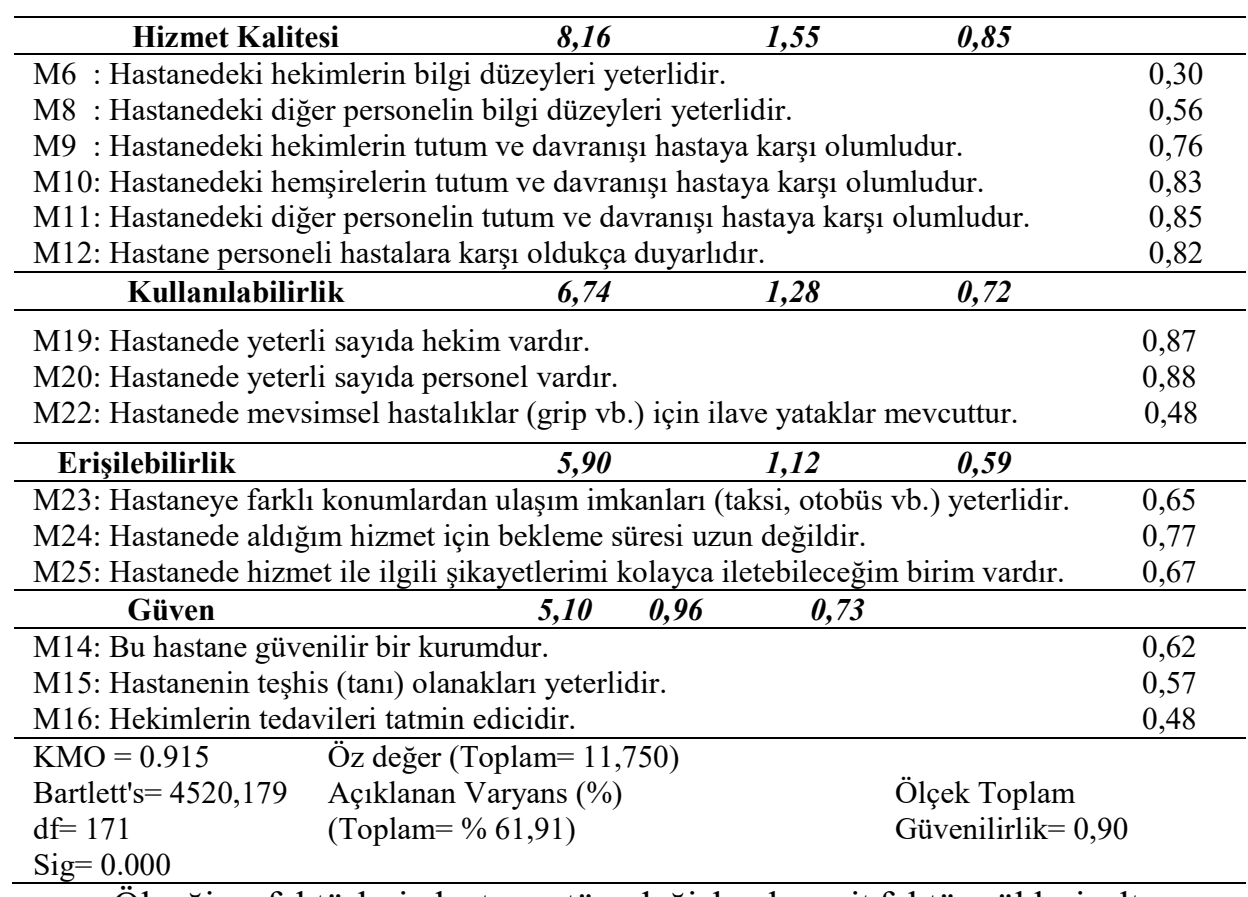

Ölçeği ve faktörleri oluşturan tüm değişkenlere ait faktör yükleri, alt sınırın $(0,30)$ üzerinde yer aldıklarından, iç tutarlılığın ve güvenilirliğin sağlandığı görülmektedir.

Yapılan faktör analizi sonucunda ifadelerin faktör yükleri 0.30 ile 0.88 arasında yer almaktadır. Ayrıca KMO değerinin 0,91 olmas1 ve Barlett's testinin anlamlı sonuç vermesi, her bir boyut için toplanan verilerin araştırmada kullanılan ölçekle uyumlu bir şekilde faktörler altında toplanabileceğini ve araştırma konusu ile ilgili yazını desteklediğini göstermektedir. Araştırma modelinde yer alan beş faktörden, fiziksel şartlar faktörü toplam varyansın $\%$ 36,00'ını, hizmet kalitesi faktörü \% \% 8,16'sını, kullanılabilirlik faktörü \% 6,74'ünü erişilebilirlik faktörü \% 5,90'ını, güven faktörü ise \% 5,10'unu açıklamaktadır.

\subsection{MiY Algısı Ölçeğinin DFA ile Test Edilmesi}

Açıklayıcı faktör analizi ile yapısal geçerlilik test edildikten sonra, kullanılan ölçeğin örneğe uygunluğunu test etmek amaciyla ölçekteki gözlenen değişkenlerin birden fazla faktör altında toplanmış olması sebebiyle, birinci düzey çok faktörlü DFA modeli kullanılmıştır. Model uyum değerleri Tablo 3 'te, regresyon katsayıları Tablo 4'te, model uyum diyagramı ise Şekil 1' de gösterilmiştir.

Model uyumu (model fit) için, model ile veri arasındaki uyumu test ederken, uyum iyiliği testlerinden birkaçı kullanılabildiği gibi, hepsinin de 
Hastaların Müş̧teri İlişkileri Yönetimi Uygulamalarına İlişkin Algı Düzeylerinin Yapısal Eşitlik Modeli İle İncelenmesi

kullanılması tercih edebilir. $\mathrm{Bu}$ uyum iyiliği istatistiklerinden hangisinin kullanılacağına dair literatürde tam bir uzlaşı bulunmamaktadır (Schumacker, 2006: 118). Model uyumunun (model fit) sağlandığını gösteren değerler; RMSEA, NFI, CFI, IFI, GFI değerleridir ve bu değerlerin mükemmel uyumları (Karagöz, 2019: 737) ile araştırma modelinin uyum değerleri Tablo 4' te görülmektedir.

Tablo 4: Yapısal Model İçin Uyum Değerleri

\begin{tabular}{lcc}
\hline Model Uyum İndeksleri & Model Uyum Değerleri & Mükemmel Uyum Değerleri \\
\hline $\mathrm{X}^{2} / \mathrm{sd}$ & $\mathbf{2 , 5 3}$ & $0<\mathrm{X}^{2} / \mathrm{sd}<3$ \\
\hline RMSEA & 0.04 & $0.00 \leq \mathrm{RMSEA} \leq 0.05$ \\
\hline $\mathrm{NFI}$ & 0.92 & $0.95 \leq \mathrm{NFI} \leq 1.0$ \\
\hline CFI & 0.95 & $0.95 \leq \mathrm{CFI} \leq 1.0$ \\
\hline IFI & 0.95 & $0.95 \leq \mathrm{IFI} \leq 1.0$ \\
\hline GFI & 0.94 & $0.90 \leq \mathrm{GFI} \leq 1.0$ \\
\hline
\end{tabular}

Tabloda görüldügü gibi (X2)/sd oranı referans değerinin altında ve 2,53 olarak bulunmuştur. RMSEA 0,04 ile mükemmel uyum düzeyindedir. NFI, CFI, GFI ve AGFI değerleri de mükemmel uyum düzeyindedir.

Tablo 5'te regresyon katsayıları (regression weights) verilmiştir. Regresyon katsayıları faktör yüklenimlerinin önemli olup olmadığını gösterir.

Tablo 5: Regresyon Katsayıları Tablosu

\begin{tabular}{lllllll}
\hline & & & Tahmin & St.Hata & C.R. & P \\
\hline M1 & $<---$ & Fiziksel Şartlar & 1,000 & & & \\
M2 & $<---$ & Fiziksel Şartlar &, 945 &, 050 & 18,763 & $* * *$ \\
M3 & $<---$ & Fiziksel Şartlar & 1,052 &, 058 & 18,002 & $* * *$ \\
M4 & $<---$ & Fiziksel Şartlar &, 748 &, 058 & 12,856 & $* * *$ \\
M6 & $<---$ & Hizmet Kalitesi & 1,000 & & & \\
M8 & $<---$ & Hizmet Kalitesi & 1,094 &, 101 & 10,871 & $* * *$ \\
M9 & $<---$ & Hizmet Kalitesi & 1,437 &, 121 & 11,884 & $* * *$ \\
M10 & $<---$ & Hizmet Kalitesi & 1,676 &, 133 & 12,569 & $* * *$ \\
M11 & $<---$ & Hizmet Kalitesi & 1,515 &, 123 & 12,312 & $* * *$ \\
M12 & $<---$ & Hizmet Kalitesi & 1,463 &, 120 & 12,223 & $* * *$ \\
M19 & $<---$ & Kullanılabilirlik & 1,000 & & & \\
M20 & $<---$ & Kullanılabilirlik &, 967 &, 057 & 16,836 & $* * *$ \\
M22 & $<---$ & Kullan1labilirlik &, 604 &, 058 & 10,491 & $* * *$ \\
M23 & $<---$ & Erişilebilirlik & 1,000 & & & \\
M24 & $<---$ & Erişilebilirlik & 1,229 &, 135 & 9,073 & $* * *$ \\
M25 & $<---$ & Erişilebilirlik & 1,242 &, 137 & 9,092 & $* * *$ \\
M14 & $<---$ & Güven & 1,000 & & & \\
M15 & $<---$ & Güven & 1,138 &, 082 & 13,845 & $* * *$ \\
M16 & $<---$ & Güven & 1,125 &, 084 & 13,385 & $* * *$ \\
\hline$* * *$ P $<0,001$ & & & & &
\end{tabular}


Tablo 5' teki verilere göre her ikili ilişki için "p" değerleri 0,05'ten küçük olduğu için, faktör yüklenimleri önemlidir. Faktör yüklenimlerinin önemli çıkması maddelerin, faktörlere doğru yüklendiği anlamına gelmektedir (Karagöz, 2019: 804).

Müşteri ilişkileri yönetimi algısı ölçeğindeki değişkenlerin faktör yükleri ve hata varyansları Şekil 2'de gösterilmiştir.

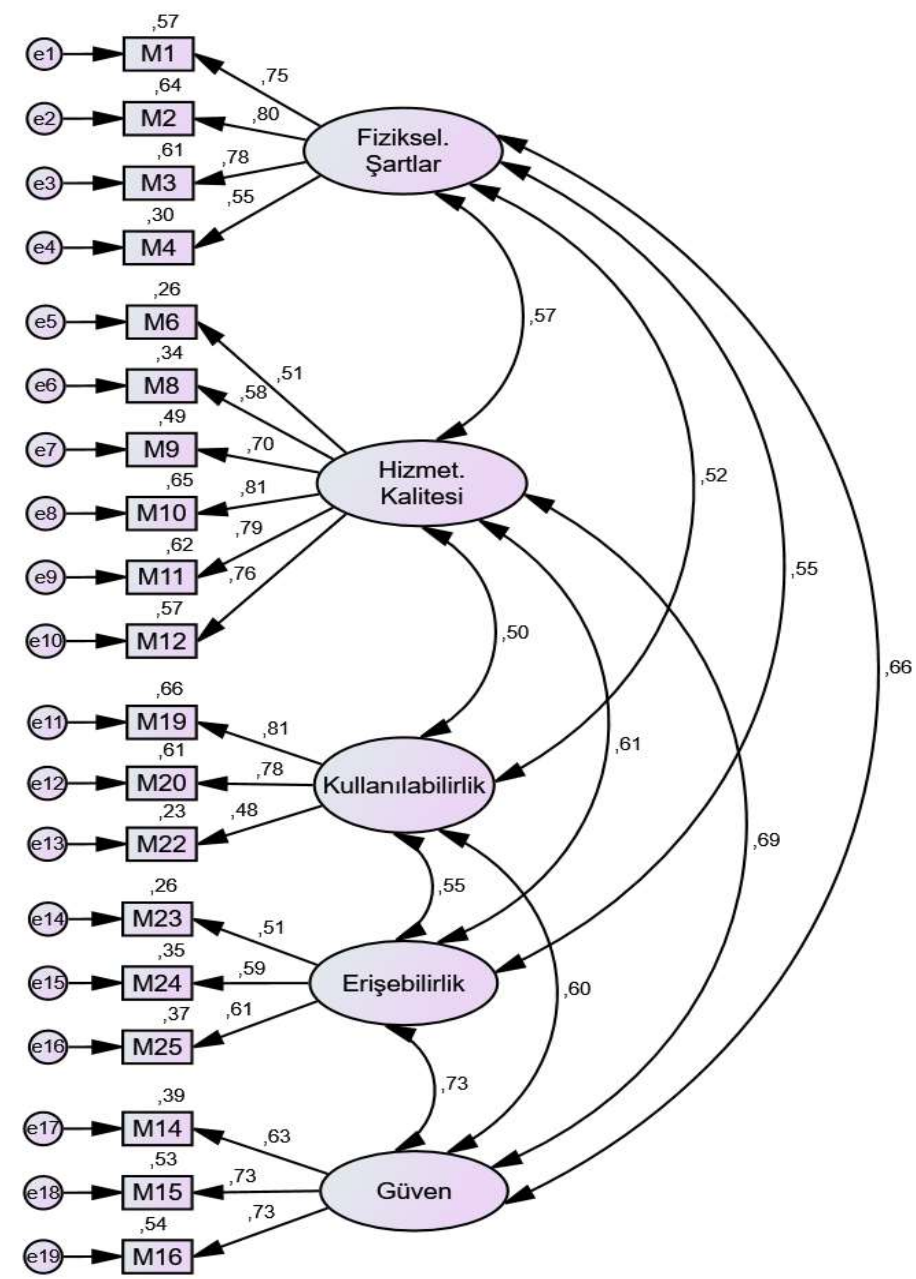

Chi-Square $=359,420 \quad \mathrm{df}=142 \quad$ P-value $=0,000$

Şekil 2: MiY Alglsı Ölçeği DFA Sonuçları

DFA sonuçları değerlendirilirken her bir maddenin faktör yük değerlerinin incelenmesi ve her birinin 0,30 ve üzeri bir yük değerine sahip olmasına dikkat edilmelidir (Seçer, 2017: 187). "fiziksel şartlar" gizil değişkenindeki tüm maddelerin faktör yüklerinin 0,55 ile 0,80 arasında; "hizmet kalitesi" gizil 
Hastaların Müsteri Illişkileri Yönetimi Uygulamalarına İlişkin Algı Düzeylerinin Yapısal Eşitlik Modeli İle İncelenmesi

değişkenindeki tüm maddelerin faktör yüklerinin 0,51 ile 0,81 arasında; "kullanılabilirlik" gizil değişkenindeki tüm maddelerin faktör yüklerinin 0,48 ile 0,81 arasında; "erişilebilirlik" gizil değişkenindeki tüm maddelerin faktör yüklerinin 0,51 ile 0,61 arasında ve "güven" gizil değişkenindeki tüm maddelerin faktör yüklerinin 0,63 ile 0,73 arasında değiştiği, alt boyutların hiçbirinde sorunlu madde bulunmadığı tespit edilmiştir. Bununla beraber; tüm gizil değişkenler arasında da 50-73 arasında değişen güçlü bir ilişki olduğu saptanmıştır.

Elde edilen sonuçlar bir arada değerlendirildiğinde ölçeğin güvenilir ve geçerli olduğu bulgusu elde edilmiştir (Tablo 3-4-5; Şekil 1).

5.3. Müşteri İlişkileri Yönetimi Algısı Ölçeğinin Betimsel İstatistikleri

Katılımcıların müşteri ilişkileri yönetimi algı düzeyleri ve standart sapmalarına ilişkin veriler Tablo 6' da sunulmuştur.

Tablo 6: Müşsteri İlişskileri Yönetimi (MIY) Algısı Ölçeğinin Betimsel İstatistikleri

\begin{tabular}{lccccc}
\hline Ölçek & n & En düş. puan & En yük. puan & Ort. & ss \\
\hline MíY Genel Algı & 390 & 21 & 95 & 61,47 & 12,77 \\
\hline F1 (Fiziksel Şartlar) & 390 & 4 & 20 & 12,58 & 3,72 \\
\hline F2 (Hizmet Kalitesi) & 390 & 6 & 30 & 19,88 & 4,90 \\
\hline F3 (Kullanılabilirlik) & 390 & 3 & 15 & 9,56 & 2,69 \\
\hline F4 (Erişilebilirlik) & 390 & 3 & 15 & 9,22 & 2,68 \\
\hline F5 (Güven) & 390 & 3 & 15 & 10,21 & 2,56 \\
\hline
\end{tabular}

Tablo 6 incelendiğinde, hastaların müşteri ilişkileri yönetimi uygulamalarına ilişkin algı düzeylerinin yüksek olduğu $(100 * 61,47 / 95=64,70)$ saptanmıştır. Faktörler değerlendirildiğinde, en yüksek puanı güven faktörü alırken, en düşük puanı erişilebilirlik faktörünün aldığı görülmektedir. Buna göre, hastalar sağlık ekibine güvenmektedir fakat erişme konusunda sıkıntı yaşamaktadır denilebilir. MiY için önemli bir kriter olan hizmet kalitesi faktörü de yüksek bir düzeye sahiptir.

5.4. Hastaların Müşteri İlişkileri Yönetimi Algı Düzeylerinin Çeşitli Değişkenlere Göre İncelenmesi

Araştırmada kullanılan verilerin normal dağılıp dağılmadığına yönelik yapılan analiz sonucunda "müşteri ilişkileri yönetimi algısı" ölçeğine ait verilerin normal dağılım göstermediği belirlenmiş; ancak normal dağılımın diğer varsayımları olan basıklık ve çarpıklık değerlerinin $\pm 1,5$ arasında olması (Tabachnick and Fidell, 2013), ortalama ve medyan değerlerinin birbirine yakın olmas1 ve örneklem hacminin merkezi limit teoremi gereği 30 veya üzerinde olması sebebiyle (Karagöz, 2019: 352), ölçeğe ait verilerin normal dağılımdan çok fazla uzaklaşmadığı sonucuna varılmıştır. Zira sosyal bilimlerde insana ait daha soyut kavramların teste tabi tutulmasından ötürü normal dağ 11 lım göstermemesi olağan kabul edilmektedir. $\mathrm{Bu}$ sebeple analizlere parametrik testlerle devam edilmiştir. 
Tablo 7: MIY Algisı Ölçeğinin ve Faktörlerin Cinsiyet Değişkenine Göre Farklılaşma Durumuna Ait Bağımsız Örneklem T-Testi Sonuçları

\begin{tabular}{|c|c|c|c|c|c|c|}
\hline MiY & Cinsiyet & n & Ort. & SS & $\mathbf{t}$ & p \\
\hline \multirow{2}{*}{ F1 } & Kadın & 218 & 12,25 & 3,72 & \multirow{2}{*}{$-1,99$} & \multirow{2}{*}{$0,04 *$} \\
\hline & Erkek & 172 & 13,01 & 3,69 & & \\
\hline \multirow{2}{*}{ F2 } & Kadın & 218 & 19,64 & 5,11 & \multirow{2}{*}{$-1,07$} & \multirow{2}{*}{0,28} \\
\hline & Erkek & 172 & 20,18 & 4,60 & & \\
\hline \multirow{2}{*}{ F3 } & Kadın & 218 & 9,54 & 2,83 & \multirow{2}{*}{$-0,16$} & \multirow{2}{*}{0,86} \\
\hline & Erkek & 172 & 9,58 & 2,52 & & \\
\hline \multirow{2}{*}{ F4 } & Kadın & 218 & 9,29 & 2,67 & \multirow{2}{*}{$-0,16$} & \multirow{2}{*}{0,57} \\
\hline & Erkek & 172 & 9,13 & 2,70 & & \\
\hline \multirow{2}{*}{ F5 } & Kadın & 218 & 10,18 & 2,58 & \multirow{2}{*}{0,56} & \multirow{2}{*}{0,80} \\
\hline & Erkek & 172 & 10,25 & 2,54 & & \\
\hline \multirow{2}{*}{$\begin{array}{l}\text { MiY Genel } \\
\text { Ortalama }\end{array}$} & Kadın & 218 & 60,92 & 13,14 & \multirow{2}{*}{$-0,96$} & \multirow{2}{*}{0,34} \\
\hline & Erkek & 172 & 62,17 & 12,29 & & \\
\hline
\end{tabular}

Analiz sonuçlarına göre hastaların müşteri ilişkileri yönetimi uygulamalarına ve fiziksel şartlar dışındaki faktörlere ilişkin algı düzeylerinde cinsiyet değişkeni açısından istatistiksel olarak anlamlı farklılık olmamakla ( $>0,05)$ tespit edilmemiştir. Dolayısıyla $\mathrm{H}_{1}$ hipotezi reddedilmiştir.

Tablo 8: MiY Algısı Ölçeğinin ve Faktörlerin Medeni Durum Değisşkenine Göre Farklılaşma Durumuna Ait Bağımsız Örneklem T-Testi Sonuçları

\begin{tabular}{|c|c|c|c|c|c|c|}
\hline MíY & $\begin{array}{l}\text { Medeni } \\
\text { Durum }\end{array}$ & n & Ort. & sS & $\mathbf{T}$ & $\mathbf{p}$ \\
\hline \multirow{2}{*}{ F1 } & Evli & 231 & 12,83 & 3,80 & \multirow{2}{*}{1,54} & \multirow{2}{*}{0,12} \\
\hline & Bekar & 159 & 12,23 & 3,58 & & \\
\hline \multirow{2}{*}{ F2 } & Evli & 231 & 20,26 & 5,80 & \multirow{2}{*}{1,84} & \multirow{2}{*}{0,06} \\
\hline & Bekar & 159 & 19,32 & 4,58 & & \\
\hline \multirow{2}{*}{ F3 } & Evli & 231 & 9,87 & 2,65 & \multirow{2}{*}{2,74} & \multirow{2}{*}{$0,00^{*}$} \\
\hline & Bekar & 159 & 9,11 & 2,71 & & \\
\hline \multirow{2}{*}{ F4 } & Evli & 231 & 9,27 & 2,72 & \multirow{2}{*}{0,41} & \multirow{2}{*}{0,67} \\
\hline & Bekar & 159 & 9,15 & 2,63 & & \\
\hline \multirow{2}{*}{ F5 } & Evli & 231 & 10,39 & 2,59 & \multirow{2}{*}{1,68} & \multirow{2}{*}{0,09} \\
\hline & Bekar & 159 & 9,94 & 2,51 & & \\
\hline \multirow{2}{*}{$\begin{array}{l}\text { MİY Genel } \\
\text { Ortalama }\end{array}$} & Evli & 231 & 62,63 & 13,05 & \multirow{2}{*}{2,17} & \multirow{2}{*}{$0,03 *$} \\
\hline & Bekar & 159 & 59,78 & 12,20 & & \\
\hline
\end{tabular}

Medeni durum değişkenine göre farklılığın incelendiği Tablo 8' de görüleceği üzere medeni durum ile müşteri ilişkileri yönetimi uygulamalarına ve F3 (Kullanılabilirlik) boyutuna ilişkin algı düzeylerinde anlamlı farklılıklar var olduğu $(\mathrm{p}<0,05)$ ve evli bireylerin alg1 düzeylerinin daha yüksek olduğu görülmüştür. Dolayısıyla $\mathrm{H}_{2}$ hipotezi kabul edilmiştir. 
Hastaların Müşteri İlişkileri Yönetimi Uygulamalarına İlişkin Algı Düzeylerinin Yapısal Eşitlik Modeli İle İncelenmesi

Tablo 9: MIY Algısı Ölçeğinin ve Alt Faktörlerinin Gelir Değişkenine Göre Farklılaşma Durumuna Ait Tek Yönlü ANOVA Testi Sonuçları

\begin{tabular}{|c|c|c|c|c|c|c|}
\hline MiY & $\begin{array}{l}\text { D. Sağlık } \\
\text { Kontrolü }\end{array}$ & $\mathbf{n}$ & Ort. & ss & $\mathbf{t}$ & $\mathbf{p}$ \\
\hline \multirow{2}{*}{ F1 } & Evet & 179 & 12,68 & 3,85 & \multirow{2}{*}{0,47} & \multirow{2}{*}{0,63} \\
\hline & Hayır & 211 & 12,50 & 3,61 & & \\
\hline \multirow{2}{*}{ F2 } & Evet & 179 & 20,89 & 4,83 & \multirow{2}{*}{3,81} & \multirow{2}{*}{$0,00 *$} \\
\hline & Hayır & 211 & 19,02 & 4,80 & & \\
\hline \multirow{2}{*}{ F3 } & Evet & 179 & 9,70 & 2,76 & \multirow{2}{*}{0,99} & \multirow{2}{*}{0,31} \\
\hline & Hayır & 211 & 9,43 & 2,64 & & \\
\hline \multirow{2}{*}{ F4 } & Evet & 179 & 9,69 & 2,80 & \multirow{2}{*}{3,20} & \multirow{2}{*}{$0,01^{*}$} \\
\hline & Hayır & 211 & 8,82 & 2,52 & & \\
\hline \multirow{2}{*}{ F5 } & Evet & 179 & 10,64 & 2,51 & \multirow{2}{*}{3,07} & \multirow{2}{*}{$0,02 *$} \\
\hline & Hayır & 211 & 9,84 & 2,56 & & \\
\hline \multirow{2}{*}{$\begin{array}{l}\text { MiY Genel } \\
\text { Ortalama }\end{array}$} & Evet & 179 & 63,62 & 12,76 & \multirow{2}{*}{3,09} & \multirow{2}{*}{$0,02 *$} \\
\hline & Hayır & 211 & 59,64 & 12,52 & & \\
\hline
\end{tabular}

MiYY algısı ölçeğinin ve faktörlerinin düzenli sağlık kontrolü değişkenine göre farklılaşma durumuna ait bağımsız örneklem t-testi sonuçları tablo 9'da sunulmuştur. Buna göre düzenli sağlık kontrollerinden geçen bireylerin alg1 düzeyleri düzenli sağlık kontrollerinden geçmeyen bireylere göre daha yüksek çıkmıştır. Fakat istatistiksel olarak anlamlı fark; MiY algısına yönelik ifadelere ait genel ortalamada ve F2 (Hizmet kalitesi), F4 (Erişilebilirlik), F5 (Güven) faktörlerine ait ifadelere ilişkin ortalamalarda görülmektedir. Dolayısıyla $\mathrm{H}_{3}$ hipotezi kabul edilmiştir.

Tablo 10. MiY Alglsı Ölçeğinin ve Faktörlerin Yaş Değişkenine Göre Farklılaşma Durumuna Ait Tek Yönlü ANOVA Testi Sonuçları

\begin{tabular}{|c|c|c|c|c|c|c|}
\hline MIY & Yaş & $\mathbf{n}$ & Ort, & ss & $\mathbf{F}$ & $\mathbf{p}$ \\
\hline \multirow{4}{*}{ F1 } & $18-29^{(1)}$ & 111 & 12,14 & 3,60 & \multirow{4}{*}{3,16} & \multirow{4}{*}{$0,02 *$} \\
\hline & $30-44^{(2)^{*}}$ & 109 & 12,08 & 3,64 & & \\
\hline & $45-59^{(3)}$ & 89 & 12,92 & 3,83 & & \\
\hline & 60 ve üstü ${ }^{(4) *}$ & 81 & 13,51 & 3,72 & & \\
\hline \multirow{4}{*}{ F2 } & $18-29^{(1)}$ & 111 & 19,14 & 4,83 & \multirow{4}{*}{1,84} & \multirow{4}{*}{0,13} \\
\hline & $30-44^{(2)}$ & 109 & 19,72 & 4,75 & & \\
\hline & $45-59^{(3)}$ & 89 & 20,23 & 5,00 & & \\
\hline & 60 ve üstü ${ }^{(4)}$ & 81 & 20,72 & 4,98 & & \\
\hline \multirow{4}{*}{ F3 } & $18-29^{(1)}$ & 111 & 9,03 & 2,73 & \multirow{4}{*}{4,15} & \multirow{4}{*}{0,06} \\
\hline & $30-44^{(2)}$ & 109 & 9,38 & 2,88 & & \\
\hline & $45-59^{(3)}$ & 89 & 9,69 & 2,43 & & \\
\hline & 60 ve üstü ${ }^{(4)}$ & 81 & 10,37 & 2,51 & & \\
\hline \multirow{4}{*}{ F4 } & $18-29^{(1)}$ & 111 & 9,41 & 2,37 & \multirow{4}{*}{2,77} & \multirow{4}{*}{0,84} \\
\hline & $30-44^{(2)}$ & 109 & 9,14 & 2,69 & & \\
\hline & $45-59^{(3)}$ & 89 & 9,10 & 3,01 & & \\
\hline & 60 ve üstü ${ }^{(4)}$ & 81 & 9,20 & 2,72 & & \\
\hline
\end{tabular}


Tablo 10 Devamı: MiY Algısı Ölçeğinin ve Faktörlerin Yaş Değişkenine Göre Farklılaşma Durumuna Ait Tek Yönlü ANOVA Testi Sonuçları

\begin{tabular}{clccccc}
\hline \multirow{4}{*}{$\mathbf{F 5}$} & $18-29^{(1)}$ & 111 & 9,94 & 2,63 & & \\
& $30-44^{(2)}$ & 109 & 10,08 & 2,60 & $\mathbf{1 , 3 7}$ & $\mathbf{0 , 2 5}$ \\
& $45-59^{(3)}$ & 89 & 10,29 & 2,66 & & \\
& 60 ve üstü(4) $^{(4)}$ MiYY Genel & 81 & 10,66 & 2,28 & & \\
Ort. & $18-29^{(1)^{*}}$ & 111 & 59,68 & 12,45 & & \\
& $30-44^{(2)}$ & 109 & 60,42 & 12,38 & $\mathbf{2 , 6 2}$ & $\mathbf{0 , 0 4 *}$ \\
& $45-59^{(3)}$ & 89 & 62,24 & 13,60 & & \\
\hline
\end{tabular}

*Anlamlı farklılığı ifade etmektedir.

MIY algısı ölçeğinin ve faktörlerinin yaş değişkenine göre farklılaşma durumuna ait Tek Yönlü ANOVA Testi sonuçları Tablo 10'da verilmiştir. Buna göre ölçeğin genelinde ve F1 (Fiziksel şartlar) faktöründe yaş değişkeni açısından istatistiksel olarak anlamlı farklılıkların var olduğu $(\mathrm{p}<0,05)$ bu farklılığın 18-29 ve 30-44 yaş ile 60 ve üstü yaş gruplarından kaynaklandığı görülmüştür. Dolayısıyla $\mathrm{H}_{4}$ hipotezi kabul edilmiştir. Genel olarak yaşla beraber müşteri ilişkileri yönetimi algı düzeyinin de artığını söylemek mümkündür.

Tablo 11. MIY Algısı Ölçeğinin Eğitim Değişkenine Göre Farklılaşma Durumuna Ait Tek Yönlü ANOVA Testi Sonuçları

\begin{tabular}{lccccc}
\hline Ĕğitim & n & Ort, & ss & F & p* $^{*}$ \\
\hline Okur-yazar değil(1) $^{(1)}$ & 38 & 61,47 & 12,88 & & \\
Ilköğretim $^{(2)}$ & 113 & 63,27 & 13,05 & & \\
Lise $^{(3)}$ & 88 & 62,18 & 12,07 & $\mathbf{1 , 8 9}$ & $\mathbf{0 , 1 1}$ \\
Lisans $^{(4)}$ & 116 & 58,87 & 13,16 & & \\
Lisansüstü $^{(5)}$ & 35 & 62,48 & 11,43 & & \\
\hline
\end{tabular}

* İstatistiksel olarak anlamlı fark olmaması sebebi ile faktör ortalamaları ayrıca tabloda gösterilmemiştir.

MIYY algısı ölçeğinin eğitim değişkenine göre farklılaşma durumuna ait Tek Yönlü ANOVA Testi sonuçları Tablo 11'de verilmiştir. Buna göre ölçeğin genelinde faktörlere ait ifadelerde eğitim değişkeni açısından istatistiksel olarak anlamlı farklılık olmadığı $(\mathrm{p}>0,05)$ saptanmıştır. Dolayısıyla $\mathrm{H}_{5}$ hipotezi reddedilmiştir.

Tablo 12. MIYY Algısı Ölçeğinin İş ve Sigorta Değişkenlerine Göre Farklılaşma

Durumuna Ait Tek Yönlü ANOVA Testi Sonuçları

\begin{tabular}{|c|c|c|c|c|c|}
\hline İş & $\mathbf{n}$ & Ort, & ss & $\mathbf{F}$ & p \\
\hline Çalışmıyor $^{(1)}$ & 207 & 61,29 & 13,38 & & \\
\hline Kamu Sektör ${ }^{(2)}$ & 91 & 60,20 & 10,87 & 1,24 & 0,29 \\
\hline Özel Sektör ${ }^{(3)}$ & 92 & 63,13 & 13,07 & & \\
\hline Sigorta & n & Ort, & SS & $\mathbf{F}$ & p \\
\hline $\mathrm{GSS}^{(1)}$ & 232 & 61,62 & 12,21 & & \\
\hline Özel Sağlık S. (2) & 117 & 62,53 & 13,53 & 2,32 & 0,09 \\
\hline Sigortam Yok ${ }^{(3)}$ & 41 & 57,56 & 13,28 & & \\
\hline
\end{tabular}

* İstatistiksel olarak anlamlı fark olmaması sebebi ile faktör ortalamaları ayrıca tabloda gösterilmemiştir. 
Hastaların Müssteri Illişkileri Yönetimi Uygulamalarına İlişkin Algı Düzeylerinin Yapısal Eşitlik Modeli İle İncelenmesi

MIYY algısı ölçeğinin iş ve sigorta değişkenlerine göre farklılaşma durumuna ait Tek Yönlü ANOVA Testi sonuçları Tablo 12'de verilmiştir. Buna göre ölçeğin geneline ve faktörlere ait ifadelerde iş ve sigorta değişkenleri açısından istatistiksel olarak anlamlı farklılık olmadığ $1(\mathrm{p}>0,05)$ saptanmıştır. Dolayısıyla $\mathrm{H}_{6}$ ve $\mathrm{H}_{7}$ hipotezleri reddedilmiştir.

Tablo 13. MIYY Algısı Ölçeğinin ve Faktörlerin Gelir Değişkenine Göre Farklılaşma Durumuna Ait Tek Yönlü ANOVA Testi Sonuçları

\begin{tabular}{|c|c|c|c|c|c|c|}
\hline MiY & Gelir & n & Ort, & SS & $\mathbf{F}$ & p \\
\hline \multirow{4}{*}{ F1 } & $1000 €$ alt1 $^{(1)}$ & 96 & 12,17 & 3,50 & \multirow{4}{*}{3,40} & \multirow{4}{*}{$0,01 *$} \\
\hline & $1.000-3000 \operatorname{aras1}^{(2)^{*}}$ & 180 & 13,14 & 3,48 & & \\
\hline & $3001-5000 \operatorname{arasi}^{(3)}$ & 73 & 12,47 & 4,07 & & \\
\hline & 5001 ve üstü ${ }^{(4)^{*}}$ & 41 & 11,31 & 4,23 & & \\
\hline \multirow{4}{*}{ F2 } & $1000 €$ alt1 $^{(1)}$ & 96 & 19,41 & 4,77 & \multirow{4}{*}{3,02} & \multirow{4}{*}{$0,03 *$} \\
\hline & $1.000-3000 \operatorname{arass}^{(2)^{*}}$ & 180 & 20,57 & 4,78 & & \\
\hline & $3001-5000 \operatorname{aras1}^{(3)}$ & 73 & 19,68 & 5,08 & & \\
\hline & 5001 ve üstü ${ }^{(4)^{*}}$ & 41 & 18,29 & 4,98 & & \\
\hline \multirow{4}{*}{ F3 } & $1000 €$ alt $^{(1)^{*}}$ & 96 & 9,23 & 2,95 & \multirow{4}{*}{4,03} & \multirow{4}{*}{$0,00 *$} \\
\hline & $1.000-3000 \operatorname{aras} 1^{(2)^{*}}$ & 180 & 10,02 & 2,40 & & \\
\hline & $3001-5000 \operatorname{aras1}^{(3)}$ & 73 & 9,36 & 2,90 & & \\
\hline & 5001 ve üstü ${ }^{(4)^{*}}$ & 41 & 8,63 & 2,60 & & \\
\hline \multirow{4}{*}{ F4 } & $1000 £$ alt1 $^{(1)}$ & 96 & 9,01 & 2,58 & \multirow{4}{*}{4,46} & \multirow{4}{*}{$\mathbf{0 , 7 0}$} \\
\hline & $1.000-3000 \operatorname{arasi}^{(2)}$ & 180 & 9,33 & 2,72 & & \\
\hline & $3001-5000 \operatorname{arasi}^{(3)}$ & 73 & 9,35 & 2,71 & & \\
\hline & 5001 ve üstü(4) & 41 & 9,00 & 2,72 & & \\
\hline \multirow{4}{*}{ F5 } & $1000 €$ alt1 ${ }^{(1)}$ & 96 & 9,63 & 2,58 & \multirow{4}{*}{5,46} & \multirow{4}{*}{$0,00 *$} \\
\hline & $1.000-3000 \operatorname{aras1}^{(2)^{*}}$ & 180 & 10,68 & 2,28 & & \\
\hline & $3001-5000 \operatorname{aras1}^{(3)}$ & 73 & 10,28 & 2,76 & & \\
\hline & 5001 ve üstü ${ }^{(4)^{*}}$ & 41 & 9,34 & 2,89 & & \\
\hline \multirow{4}{*}{$\begin{array}{l}\text { MíY Genel } \\
\text { Ort. }\end{array}$} & $1000 €$ alt $^{(1)^{*}}$ & 96 & 59,47 & 13,04 & \multirow{4}{*}{4,87} & \multirow{4}{*}{$0,02 *$} \\
\hline & $1.000-3000 \operatorname{aras1}^{(2)^{*}}$ & 180 & 63,77 & 11,81 & & \\
\hline & $3001-5000 \operatorname{aras1}^{(3)}$ & 73 & 61,17 & 13,37 & & \\
\hline & 5001 ve üstü ${ }^{(4) *}$ & 41 & 56,58 & 13,40 & & \\
\hline
\end{tabular}

MIY algısı ölçeğinin ve faktörlerinin gelir değişkenine göre farklılaşma durumuna ait Tek Yönlü ANOVA Testi sonuçları Tablo 13'te verilmiştir. Buna göre gelir değişkeni açısından F4 (Erişilebilirlik) faktörü dışında ölçeğin geneline ve diğer faktörlerine ait ifadelerde istatistiksel olarak anlamlı farklılık $(p<0,05)$ görülmekte olup, bu farklılığın 1.000-3.000 € arası ile $1.000 €$ altı ve $5001 €$ ve üstü gelir seviyesinde olduğu görülmektedir Dolayısıyla $\mathrm{H}_{8}$ hipotezi kabul edilmiştir. Fakat gelir seviyesi ile algı düzeyi arasındaki fark orantısal değildir.

\section{Sonuç ve Tartışma}

Sivas Cumhuriyet Üniversitesi Sağlık Hizmetleri Uygulama ve Araştırma Hastanesi'nde (SCÜH) hizmet kalitesini ve müşteri memnuniyetini sağlamayı hedef alan, müşteri ilişkileri yönetimi uygulamalarının hasta perspektifinden 
değerlendirilmesi amacıyla yapılan araştırma sonucunda elde edilen verilere göre, hastaların neredeyse yarısı işlemler için $20 \mathrm{dk}$ 'dan daha fazla beklediğini belirtmiştir. Hizmet işletmelerinde talep dalgalanmalarına bağlı olarak talebi kapasite ile uyumlaştırmak zor olmakla beraber, söz konusu hastanenin bir kamu hastanesi olması ve hizmet talep eden hasta sayısının fazla olmasinın beklemeye neden olduğu düşünülebilir. Araştırma esnasında hastaların bu bekleme süresini çok uzun bulmadıkları da gözlemlenmiştir. Ancak sağlık gibi hassas bir hizmet sunumu gerçekleştiriliyor ise rezervasyon ya da kuyruk yönetimi uygulamalarının daha etkin yürütülmesi ve beklemelerin en aza indirgenmesi gerekmektedir.

Araştırmada MIYY algısı ölçeği, yapılan açıklayıcı faktör analizi sonucunda beş faktör (fiziksel şartlar, hizmet kalitesi, kullanılabilirlik, erişilebilirlik, güven) altında incelenmiş olup, faktörler betimsel olarak değerlendirildiğinde, en yüksek puanı güven faktörü alırken, en düşük puanı erişilebilirlik faktörünün aldığı tespit edilmiştir. Hizmet sunumunun tasarımında önemli olan unsurlardan birisi de hizmet sağlanan tesise, kullanılan ekipmana ve teknolojiye veya hizmet sunucusuna erişilebilirliktir. Bununla birlikte sağlık hizmetleri gibi destekleyici ve kolaylaştırıcı hizmetler ile genişletilmiş bir hizmet sunumu söz konusu olduğunda, önemli başlıklardan biri de etkileşim ve müşterinin katılımıdır. Bu bağlamda güven duygusunun yüksek çıkması hastanenin sunmuş olduğu hizmete yönelik etkileşim unsurunun sağlandığını göstermektedir. Araştırmaya konu olan hastanenin erişilebilirlik noktasında tesis, ekipman, teknoloji ve personel hususlarına müşterinin daha etkin ulaşabilmesi adına düzenlemeler yapması gerekmektedir. Ayrıca hizmet kalitesinin yüksek algılanmasının da müşteri ilişkileri yönetimi süreçlerini planlamada hastaneye avantaj sağlayacağı düşünülmektedir.

$\mathrm{Bu}$ çalışma verilerinden elde edilen sonuçlar demografik değişkenlere göre incelendiğinde ise; katılımcıların MIY uygulamalarına yönelik algı düzeyleri ile medeni durum, yaş, sigorta türü arasında istatistiksel olarak anlamlı bir ilişki olduğu bulunmuş, cinsiyet, eğitim düzeyi, meslek arasında ise istatistiksel olarak anlamlı bir ilişki tespit edilememiştir. Bununla beraber çalışmada erkek hastaların algı düzeylerinin kadın hastalarınkinden daha yüksek çıktığı fakat bunun istatistiksel olarak anlamlı olmadığı belirlenmiştir. Bu durum kadınların süreç odaklı olmaları ve detayları değerlendirme eğilimlerinin yüksek olması ile açıklanabilir (Biçer ve Ilıman 2018).

Yine evli bireylerin MiY uygulamalarına yönelik algı düzeyleri bekar olanlara göre daha yüksek çıkmıştır. Ayrıca, katılımcıların yaşları arttıkça müşteri ilişkileri yönetimi uygulamalarına yönelik algı düzeylerinin de artığı saptanmıştır. Bu durumu yaşa ve evlilikle birlikte artan sorumluluk bilincine bağlı olarak katılımcıların farkındalık düzeylerinin artmış olabileceği varsayımı ile açıklamak mümkündür. Bu sonuçlar sağlık işletmelerinin MiY stratejilerini geliştirirken pazar segmentasyonu yapma ve hedef pazar seçiminde sundukları hizmetlerde medeni duruma ve yaşa göre çeşitlendirme yapmaları konusunda 
Hastaların Müş̧teri İlişkileri Yönetimi Uygulamalarına İlişkin Algı Düzeylerinin Yapısal Eşitlik Modeli İle İncelenmesi

değerlendirilebilir. Aynı şekilde düzenli sağlık kontrollerinden geçen bireylerde de alg1 düzeyi düzenli sağlık kontrollerinden geçmeyen bireylere göre daha yüksek bulunmuştur. Günümüzde değişen tüketici profili ile bireyci değerlerin ön plana çıktığı ve beklentilerin yüksek olduğunu söylemek mümkündür. $\mathrm{Bu}$ doğrultuda sağlık işletmeleri bir yandan sağlık hizmetlerinin kalitesini müşteri odaklı bir şekilde geliştirmeye çalışırken, bir yandan da MiY uygulamalarında sağladıkları etkinlik sayesinde müşteri tatmin, memnuniyet ve bağll1ığı yaratma çabaları ile sağlanacak olumlu ağızdan ağıza iletişimin yayılımcı etkisi sayesinde sağlık hizmetlerine olan talebin bilinçli bir şekilde artmasını sağlayabilirler. $\mathrm{Bu}$ bağlamda; Çobanoğlu (2012)'nun çalışması bu görüşü desteklemektedir.

Araştırma sonucunda, katılımcıların müşteri ilişkileri yönetimi uygulamalarına ilişkin genel algı düzeyleri orta seviyede çıkmış olup, ilgili hastanenin bu noktada müşterileri ile uzun vadeli, kalıcı ve anlamlı ilişkiler kurma konusunda daha fazla çalışması gerektiği düşünülmektedir. MiY uygulamaları ve algilanan hizmet kalitesi ne derece etkin olursa, memnuniyet ve bağl1lık da o düzeyde artacak (Kayacan, 2015; Kılıç, 2015; Almunawar ve Anshari, 2014; Çobanoğlu, 2012; Kılınç, 2012; Bişkin, 2011; Korkmaz, 2010); uzun vadede bu sonuçlar toplumun sağlık düzeyinin yükseltilmesine katkı sağlayacaktır. Nitekim yapılan araştırmalar özellikle kamu hastanelerinde hastaların aldıkları hizmetten tatmin olmadığını göstermektedir (Çobanoğlu 2012; Korkmaz, 2010). Bu çalışmalardan farklı olarak; Erdem vd. (2015)'nin Elazığ il merkezinde biri üniversite üçü Sağlık Bakanlığı hastanesi olmak üzere dört hastaneden 497 hastanın hasta memnuniyeti düzeylerini inceledikleri araştırmada; genel olarak hastaların memnuniyet düzeyinin ortanın üzerinde olduğu görülmüştür.

Müşteri ilişkileri yönetiminde önemli olan temel noktalardan biri de iç müşteri olarak nitelendirilen hizmet sunanlar ile dış müşterileri olarak nitelendirilen hizmet talep edenlerin iletişimidir. Bilhassa emek yoğun olarak çalışan ve doğrudan insanlarla iletişim halinde olan sağlık kurumlarında iletişim tartışmasız bir öneme sahiptir. Özellikle akademik düzeyde yüksek olan tıp bilgisinin hastalara doğru, hızlı ve anlaşılır bir şekilde aktarılması oldukça özen isteyen bir durumdur. Ölçek ifadelerine verilen cevaplar ve ilgili yazındaki araştırmalar da bunun önemini göstermekte olup, hastanelerin hasta-hekim ve diğer çalışanlar arasındaki iletişimi noktasında sürekli iyileştirmeler sağlamaları ve bu konuyla ilgili eğitim vermeleri gerektiği düşünülmektedir. Şöyle ki gerek çalışanlarla gerekse hastalarla olan iletişimin etkinliği MiY uygulamalarının çalışanlar tarafından benimsenmesi ve hastalar tarafından olumlu algılanmasını sağlayacak; bunun sonucunda MiY uygulamaları etkin olacaktır (Soysal vd. 2017; Yalın, 2014; Torabi, 2014; Fok vd. 2003). Araştırma sonuçlarının özeti hipotezler temelinde Tablo 14'de verilmiştir. 
Tablo 14. Hipotez Sonuçları

\begin{tabular}{|c|c|c|}
\hline $\mathrm{H}_{1}$ & $\begin{array}{l}\text { Hastaların cinsiyetleri ile müşteri ilişkileri yönetimi } \\
\text { uygulamalarına ilişkin algı düzeyleri arasında anlamlı farklılık } \\
\text { vardır. }\end{array}$ & DESTEKLENMEDİ \\
\hline $\mathrm{H}_{2}$ & $\begin{array}{l}\text { Hastaların medeni durumları ile müşteri ilişkileri yönetimi } \\
\text { uygulamalarına ilişkin algı düzeyleri arasında anlamlı farklılık } \\
\text { vardır. }\end{array}$ & DESTEKLENDİ \\
\hline $\mathrm{H}_{3}$ & $\begin{array}{l}\text { Düzenli sağlık kontrollerinden geçen hastalar ile geçmeyen } \\
\text { hastaların müşteri ilişskileri yönetimi uygulamalarına ilişkin alg1 } \\
\text { düzeyleri arasında anlaml farklılık vardır. }\end{array}$ & DESTEKLENDİ \\
\hline $\mathrm{H}_{4}$ & $\begin{array}{l}\text { Hastaların yaşları ile müşteri ilişkileri yönetimi uygulamalarına } \\
\text { ilişkin algı düzeyleri arasında anlamlı farklılık vardır. }\end{array}$ & DESTEKLENDİ \\
\hline $\mathrm{H}_{5}$ & $\begin{array}{l}\text { Hastaların eğitim düzeyleri ile müşteri ilişkileri yönetimi } \\
\text { uygulamalarına ilişkin algı düzeyleri arasında anlamlı farklılık } \\
\text { vardır. }\end{array}$ & DESTEKLENMEDİ \\
\hline $\mathrm{H}_{6}$ & $\begin{array}{l}\text { Hastaların meslekleri ile müşteri ilişkileri yönetimi } \\
\text { uygulamalarına ilişkin algı düzeyleri arasında anlamlı farklılık } \\
\text { vardır. }\end{array}$ & DESTEKLENMEDİ \\
\hline $\mathrm{H}_{7}$ & $\begin{array}{l}\text { Hastaların sağlık sigortası durumları ile müşteri ilişkileri } \\
\text { yönetimi uygulamalarına ilişkin algı düzeyleri arasında anlamlı } \\
\text { farklılık vardır. }\end{array}$ & DESTEKLENMEDİ \\
\hline $\mathrm{H}_{8}$ & $\begin{array}{l}\text { Hastaların gelir düzeyleri ile müşteri ilişkileri yönetimi } \\
\text { uygulamalarına ilişkin algı düzeyleri arasında anlamlı farklılık } \\
\text { vardır. }\end{array}$ & DESTEKLENDİ \\
\hline
\end{tabular}

Araştırma sonuçlarından yola çıkarak genel bir ifadeyle, hastanelerin müşteri ilişkileri yönetimi faaliyetlerine daha fazla önem vermeleri, müşteri veri tabanlarını doğru sınıflandırarak hizmet sunumlarını hedef kitlelerine uygun hale getirmeleri ve kaliteli hizmet sunmak için stratejiler geliştirmeleri gerektiği önerilmektedir.

Günümüz işletmelerinin farklılaşma alanlarını güçlendirmek adına yoğun olarak çaba sarf ettikleri müşteri değeri yaratacak faaliyetler, ancak standardizasyonu zor olan sağlık gibi hizmet alanlarında kalite algısını maksimize edecek şekilde müşteri ilişkileri yönetimi kabiliyetini geliştirmekle mümkün olacaktır.

\section{Kaynaklar}

Agariya, A. K., Singh, D. (2013). CRM Scale Development and Validation in Indian Public Hospitals, Journal of Health Management 15(2): 275-291. DOI: 10.1177/097206341348903.

Aktepe, C., Baş, M., Tolon, M. (2018). Müşteri İlişkileri Yönetimi, 4.Baskı, Ankara: Detay Yayıncılık.

Almunawar, M. N., and Anshari, M. (2014). Empowering customers in electronic health (e-health) through social customer relationship management. International Journal of Electronic Customer Relationship Management, 8(1/2/3), 87. doi: $10.1504 / \mathrm{ijecrm} .2014 .066887$

Bişkin, F., (2011). Sağllk İşletmelerinde Müşteri İlişskileri Yönetimi: Kamu ve Özel Sağlık İşletmelerinde Müşteri İlişkileri Yönetimi Uygulamaları 
Hastaların Müssteri İlişkileri Yönetimi Uygulamalarına İliş̧kin Algı Düzeylerinin Yapısal Eşitlik Modeli İle İncelenmesi

Araştırması, Selçuk Üniversitesi, Sosyal Bilimler Enstitüsü, Doktora Tezi, Konya.

Biçer, E. B., Ilıman, E. Sağlık Yönetimi Bölümü Öğrencilerinin Muhasebe Derslerindeki Başarılarını Etkileyen Faktörler Hakkında Görüşleri (Sivas Cumhuriyet Üniversitesi Örneği), Muhasebe Bilim Dünyas1 Dergisi, 20(4); 995-1020.

Chhangani, A. (2013). Investıgatıng Customer Relatıonshıp Management (CRM) In Indian Hospitals, International Journal of Research in Advent Technology, 1 (5): 405-408.

Choi, W., Rho, M. J., Park, J., Kim, K.-J., Kwon, Y. D., Choi, I. Y. (2013). Information System Success Model for Customer Relationship Management System in Health Promotion Centers. Healthcare Informatics Research, 19(2), 110. doi:10.4258/hir.2013.19.2.110

Çobanoğlu, V. (2012). Kamu Hastanelerinde Müşteri İlişkileri Yönetimi: Balıkesir Atatürk Devlet Hastanesi Örneği, Yüksek Lisans Tezi, Gazi Üniversitesi Sosyal Bilimler Enstitüsü, Ankara.

Çiçek, E. (2017). Pazarlamada ve Rekabette Başarının Anahtarı Müşteri Ilişskileri Yönetimi, E-Book.Konya.

Erdem, R., Rahman, S., Avc1, L., Demirel, B., Köseoğlu, S., Firat, G. Kubat, C. (2015). Hasta Memnuniyetinin Hasta Bağlılığı Üzerine Etkisi, Erciyes Üniversitesi, 31: 95-110.

Eriş, H., Ilıman, E. (2019). Sağlık Çalışanlarının Hastane Bilgi Sistemi Hakkındaki Görüşleri. Avrupa Bilim ve Teknoloji Dergisi, (16), 301-309. DOI: $10.31590 /$ ejosat.566750

Fok, W. M., Li, J., Hartman, S. J., Fok, L. Y. (2003). Customer relationship management and QM maturity: an examination of impacts in the healthcare and non-health-care setting. International Journal of Health Care Quality Assurance, 16(5), 234-247. doi:10.1108/09526860310486688

Hoşgör, H., \& Cengiz, E. (2019). İlişkisel Pazarlama Perspektifinden Hastaların Davranışsal Niyet Öncülleri: Kavramsal Bir Model Önerisi, Gümüşhane Üniversitesi Sağllk Bilimleri Dergisi, 8 (4): 501-509.

Karagöz, Y. (2019). SPSS VE AMOS Uygulamaları Bilimsel Araştırma Yöntemleri ve Yayın Etiği, 2. Baskı, Ankara: Nobel Yayıncılık.

Karagöz, N.; Ilıman, E. (2019). "Bireylerin Sağlık Hizmet Kullanım Kültürlerinin Sağlık Ekonomisi Perspektifinden Değerlendirilmesi”, International Social Mentality and Researcher Thinkers Journal, (Issn:2630-631X) 5(20): 1034-1044.

Kayacan, İ., (2015). Sağllk Isşletmelerinde Müşteri İlişkileri Yönetiminin Hasta Memnuniyetine Etkisi Üzerine Bir Araştırma, Yüksek Lisans Tezi, Süleyman Demirel Üniversitesi, Sosyal Bilimler Enstitüsü, Isparta.

Khoshraftar, A.; Yazdi, M.F.A.; Ibrahim, O.; Amini, M. Shi, M.N. Khoshraftar, A.; Talebi, A. (2011). Improving The Crm System In Healthcare 
Organızation, International Journal of Computer Engineering \& Science, 1 (2): 28-35.

Kılıç, B. C. (2015). Müşteri Illişkileri Yönetiminin Algllanan Kalite Tatmin ve Marka Sadakatine Etkisi, Yüksek Lisans Tezi, Bahçeşehir Üniversitesi, Sosyal Bilimler Enstitüsü, İstanbul.

Kılınç, C. Ç. (2012). Sağlık Sektöründe Faaliyette Bulunan Hastane İşletmelerinde Müşteri İlişkileri Yönetimi Üzerine Bir Araştırma, Review of Social, Economic \& Business Studies, 9 (10): 309-332.

Korkmaz, Ö., (2010). Müşteri Ilişskileri Yönetiminin (CRM) Önemi: Bir Hastane Uygulaması, Dokuz Eylül Üniversitesi, Sosyal Bilimler Enstitüsü, Yüksek Lisans Tezi, İzmir.

Lecturer, S. K., Kumar, K., Sarala, K.S., (2018). Customer Relationshıp Management Practices: In Health Care Sectors In Karnataka (Selected Healthcare Unit), 9 (10):12- 17.

Moreira, A. C., Carrizo, A., Silva, P.M. (2014). The Trust-Commitment Challenge in Service Quality-Loyalty Relationships, IJHCQA 28 (3): 253266.

Nakip, M. Özçifçi, V. (2015). Sağlık Hizmetlerinde İlişki Pazarlaması ve Hasta Memnuniyeti: Aksaray Aile Sağlığı Merkezlerinde Uygulama, Erciyes Üniversitesi İktisadi ve İdari Bilimler Fakültesi Dergisi, 46: 1-20.

Odabaşı, Y. (2017). Müşteri İliş̧kileri Yönetimi (CRM). 10. Basım, ,İstanbul: Agora kitaplığ1.

Oliver, R.L. (2008), "A conceptual model of service quality and service satisfaction", in Swartz, T.A., Bowen, D.E. and Brown, S.W. (Eds), Advances in Services Marketing and Management. Research and Practice, 65 (8). JAI Press, Greenwich, CT.

Sekeran, U. (2003). Research Methods for Business: A Skill Building Approach. 4th Edition, New York: John Wiley.

Soysal, A., Doğan, S., Baynal, T. (2017). Özel Sağlık Kurumlarında Müşteri İlişkileri Yönetimi, Kahramanmaraş Sütçü Imam Üniversitesi İktisadi ve İdari Bilimler Fakültesi Dergisi, 7 (1): 39-66.

Sumathy, M.; M. Tamilselvan. (2008). CRM: Concepts and implementation. In Shanmugansundaram, S. (ed.) Customer Relationship Management: Modern Trends and Perspectives (pp. 3-8). New Delhi: Prentice Hall.

Torabi, H., (2014). Müssteri İlişkileri Yönetimi Uygulamalarını Etkileyen Faktörler Üzerine Bir Araştırma, Beykent Üniversitesi, Sosyal Bilimler Enstitüsü, Yüksek Lisans Tezi, İstanbul.

Yalın, A., (2014). Müşteri Illişkileri Yönetiminde Kültür Faktörü ve Sağllk Alanında Bir Uygulama, Maltepe Üniversitesi, Sosyal Bilimler Enstitüsü, Doktora Tezi, İstanbul.

Yina, W. (2010). Application of Customer Relationship Management in Health Care. 2010 Second International Conference on Multimedia and Information Technology. doi:10.1109/mmit.2010.31 